\title{
Citra Geolistrik Resistivitas 2-Dimensi Untuk Identifikasi Zona Laterit Dan Zona Bedrock Profil Nikel Laterit
}

\author{
Ifanali Iha, Puji Hartoyo \\ Program Studi Fisika, Universitas Nasional, Jalan Sawo Manila, Pejaten, Jakarta Selatan \\ 12520 \\ Korespondensi : puji-hartoyo@yahoo.co.id
}

\begin{abstract}
Abstrak. Penelitian ini bertujuan untuk mengidentifikasi zona laterit dan zona bedrock menggunakan metode geolistrik resistivitas dan memperkirakan volume zona nikel laterit dari hasil identifikasi. Data yang digunakan pada penelitian ini diperoleh dari PT.Aneka Tambang Tbk. Pengambilan data lapangan (akuisisi data) dilakukan di daerah kuasa tambang PT. Aneka Tambang Tbk, Kecamatan Pomalaa, Kabupaten Kolaka, Sulawesi Tenggara. Metode geolistrik resistivitas merupakan salah satu metode geofisika yang sering digunakan dalam eksplorasi untuk identifikasi kandungan mineral di bawah permukaan. Metode ini dilakukan dengan cara mengalirkan arus listrik ke dalam perut bumi dan dihitung nilai resistivitas batuan saat dialiri arus listrik. Endapan nikel laterit terbentuk dari hasil pelapukan batuan ultramafik. Daerah Pomalaa adalah salah satu daerah yang memiliki potensi nikel laterit paling besar. Pengolahan data dilakukan menggunakan Software Res2dInv dan Surfer 12. Hasil dari pengolahan data adalah nilai resistivitas dan kedalaman dari profil nikel laterit. Resistivitas dari zona top soil (overburden) adalah $120-750$ ohm.m, resistivitas dari zona laterit adalah 0-120 ohm.m, dan resistivitas dari zona bedrock lebih dari $200 \mathrm{ohm} . \mathrm{m}$. Kedalaman dari zona top soil (overburden) adalah 0$30 \mathrm{~m}$, kedalaman dari zona laterit adalah 10-60 m, dan kedalaman dari zona bedrock berada lebih dari $50 \mathrm{~m}$. Dengan perkiraan luas daerah sebesar $99.000 \mathrm{~m}^{2}$ dan ketebalan zona laterit $30 \mathrm{~m}$ di bawah permukaan diperoleh volume zona nikel laterit sebesar $2.970 .000 \mathrm{~m}^{3}$.
\end{abstract}

Kata kunci: citra geolistrik, identifikasi zona, laterit, bedrock, profil nikel.

\begin{abstract}
This study aims to identify laterite zone and bedrock zone using electrical resistivity method and estimate the nickel laterite zone volume from identification results. The data used in this study were obtained from PT. Aneka Tambang Tbk. Data acquisition was conducted in the mining concession area of PT. Aneka Tambang Tbk, Pomalaa, Kolaka, Southeast Sulawesi. The electrical resistivity method is one of the most geophysical methods commonly used in exploration for identification of subsurface mineral content. This method is done by flowing the electric current into the earth and calculated the value of rock resistivity when the electric current is flowing. The nickel laterite precipitates are formed from ultramafic rock weathering. Pomalaa area is one of the areas with the greatest potential of nickel laterite. The Data processing was done using Res2DInv and Surfer 12 Software. The results of data processing are resistivity and depth value of nickel laterite profile. The resistivity of top soil (overburden) is 120-750 ohm.m, the resistivity of laterite zone is 0-120 $\mathrm{ohm} . \mathrm{m}$, and the resistivity of bedrock zone is more than $200 \mathrm{ohm} . \mathrm{m}$. The depth of top soil (overburden) zone is 0-30 m, the depth of laterite zone is $10-60 \mathrm{~m}$, and the depth of bedrock zone is more than $50 \mathrm{~m}$. With an approximation of the area is $99,000 \mathrm{~m}^{2}$ and the thickness of laterite zone is $30 \mathrm{~m}$ in the subsurface, the volume of laterite zone is $2,970,000 \mathrm{~m}^{3}$.
\end{abstract}

Keywords: geoelectric image, zone identification, laterit, bedrock, nickel profile.

\section{PENDAHULUAN}

Dalam 30 tahun terakhir, metode-metode klasik survei geolistrik resistivitas telah banyak mengalami perubahan seiring berkembangnya ilmu pengetahuan. Teknik lama untuk 
interpretasi resistivitas, yaitu teknik horizontal (1D) dengan cepat diganti oleh model interpretasi 2-Dimensi (2D) atau 3-Dimensi (3D). Berbagai masalah hidrologi, lingkungan dan geoteknik khususnya pada media bawah permukaan yang kompleks dan heterogen diatasi dengan pencitraan resistivitas $2 \mathrm{D}$ atau 3D. Nikel laterit merupakan salah satu mineral logam yang dihasilkan dari industri pertambangan. Endapan nikel laterit terbentuk dari hasil pelapukan batuan induk dari jenis ultramafik. Pada umumnya nikel laterit terbentuk pada iklim tropis sampai sub-tropis. Negara penghasil nikel laterit di dunia di antaranya New Caledonia, Kuba, Philippines, Indonesia, Columbia dan Australia. Kebutuhan akan mineral nikel yang cukup besar di dalam dunia industri, mengakibatkan kegiatan eksplorasi sebagai langkah awal kegiatan pertambangan terus menerus dilakukan. Untuk melakukan eksploitasi nikel laterit, terlebih dahulu dilakukan kegiatan eksplorasi dengan menggunakan metode geofisika. Salah satu metode geofisika yang dapat digunakan dalam eksplorasi nikel laterit adalah metode geolistrik resistivitas.

Beberapa kegiatan eksplorasi dilakukan menggunakan metode geolistrik resistivitas. Telah dilakukan penelitian menggunakan metode geolistrik resistivitas inversi 3D dari data survei profil 2D orthogonal di dalam kampus University of Ibadan,Nigeria [1]. Penelitian tersebut bertujuan menyelidiki tingkat pelapukan dan rekahan dalam penampang tanah yang mengalami pelapukan dan memastikan kesesuaian lokasi untuk dilakukan pembangunan serta menentukan potensi air tanahnya. Pencitraan 3D dan 2D geolistrik resistivitas telah efektif digunakan dalam investigasi di daerah yang akan dilakukan pembangunan. Penelitian lainnya menggunakan metode geolistrik dan metode seismik untuk investigasi daerah karst pada dataran Omalos di Chania, Barat crete, Yunani. Data yang diperoleh dari metode geolistrik dan seismik di dataran Omalos mencitrakan struktur karts dari karbonat metamorf yang ditutup pasca-Mesozoikum [2]. Penelitian dengan menggunakan geolistrik resistivitas juga dilakukan di daerah Entrop Kota Jayapura, Papua, untuk menentukan profil nikel laterit [3]. Hasil pengolahan data dari geolistrik resistivitas 2D diperoleh profil nikel laterit dengan mengkorelasikan data geologi.

Metode geolistrik resistivitas 2D telah efektif dan efisien digunakan untuk mengidentifikasi profil nikel laterit. Oleh karena itu, pada penyeledikan zona laterit dan zona bedrock dari profil nikel laterit di daerah kuasa tambang PT. Aneka Tambang Tbk, Kecamatan Pomalaa, Kabupaten Kolaka, Sulawesi Tenggara digunakan metode geolistik resistivitas profil 2D.

\section{METODE}

Pencitraan 2D geolistrik resistivitas dapat diperoleh dengan mengitegrasikan teknik vertical electrical sounding (VES) dengan penampang (profil) elektrik. Hal ini melibatkan pengukuran resistivitas semu di sepanjang garis ditempatkannya elektroda . Prosedur ini diulang sebanyak kombinasi dari posisi elektroda arus dan potensial seperti yang didefinisikan oleh konfigurasi survei. Pencitraan resistivitas 2D dapat dilihat sebagai continuous vertical electrical sounding (CVES) di mana sejumlah VES dilakukan dalam kotak yang digabung bersama-sama atau sebagai kombinasi dari penampang dengan meningkatkan jarak elektroda.

\section{a). 10 Model}

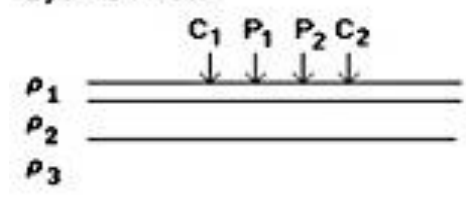

b). 20 Model

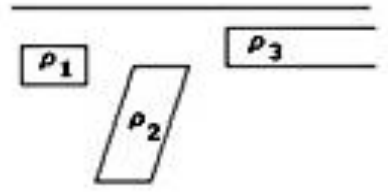

c). 3D Model

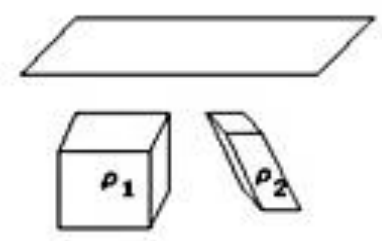

Gambar 1. Tiga Model Yang Digunakan Dalam Interpretasi Pengukuran Resistivitas [6]. 
Metode resistivitas 2-Dimensi (2D) biasanya dilakukan dengan menggunakan sejumlah besar elektroda yang terhubung ke kabel multi-core. Untuk sistem dengan sejumlah elektroda, daerah yang dicakup oleh survei dapat diperpanjang sepanjang garis survei menggunakan teknik roll-along. Hal ini dapat dicapai dengan memindahkan salah satu kabel di ujung garis beberapa unit elektroda yang berjarak, setelah menyelesaikan urutan pengukuran . Sejumlah konfigurasi telah digunakan dalam pencatatan data lapangan resistivitas 2D geolistrik, masing-masing cocok untuk situasi geologi tertentu. Konfigurasi konvensional yang paling umum digunakan adalah Wenner alpha, dipol-dipol, pol-pol dan pol-dipol. Sebagian besar survei 2D geolistrik resistivitas dilakukan dengan menggunakan konfigurasi Wenner Alpha.

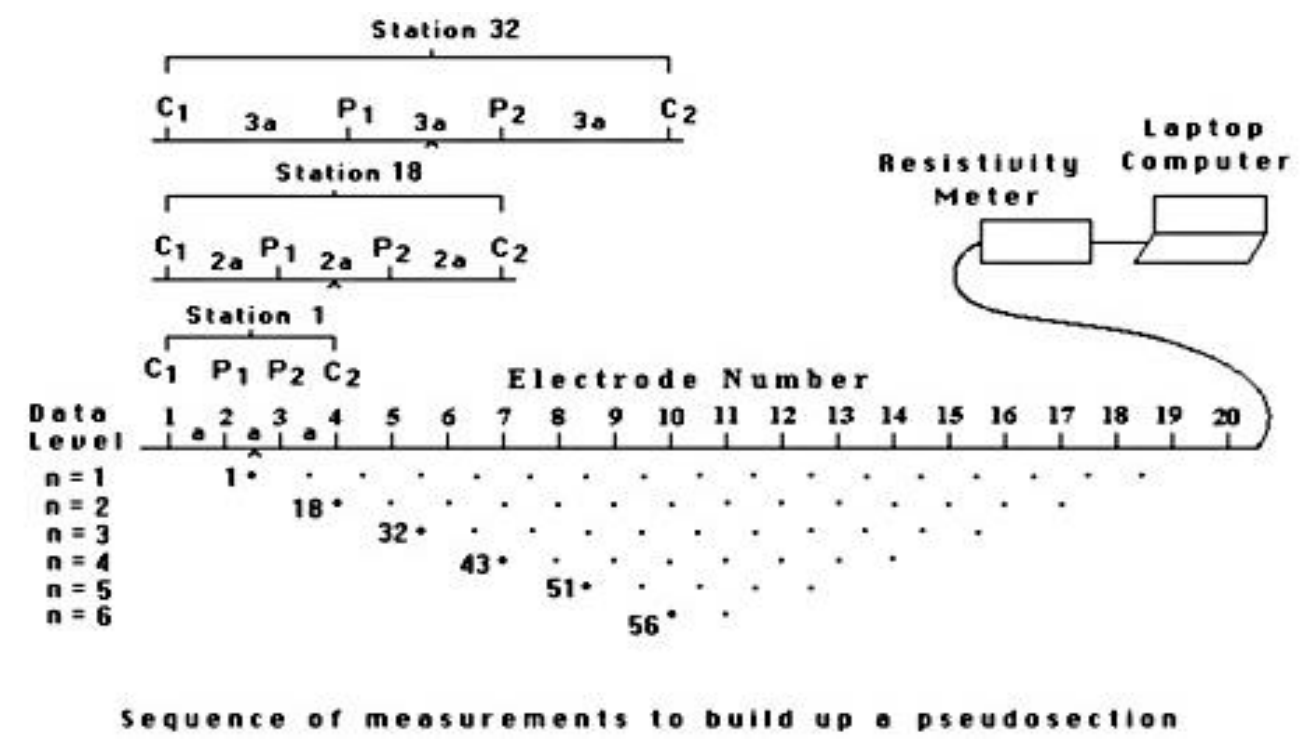

Gambar 2. Susunan Elektoda Untuk Survei Geolistrik 2D [6].

Dalam penelitian ini langkah-langkah yang dilakukan antara lain pengambilan data lapangan. Data yang diperoleh dari lapangan berupa nilai-nilai resistansi material tanah berupa resitivitas semu. Data tersebut kemudian diinversikan menggunakan Res2Dinv. Hasil inversi dari Res2Dinv yang diperoleh diekspor ke bentuk surfer kemudian disajikan dalam bentuk citra profil 2D oleh software Surfer 12. Citra profil 2D digunakan untuk memperkirakan volume lapisan laterit nikel. Hasil citra profil 2D dianalisis dan diinterpretasi kemudian diambil kesimpulan.

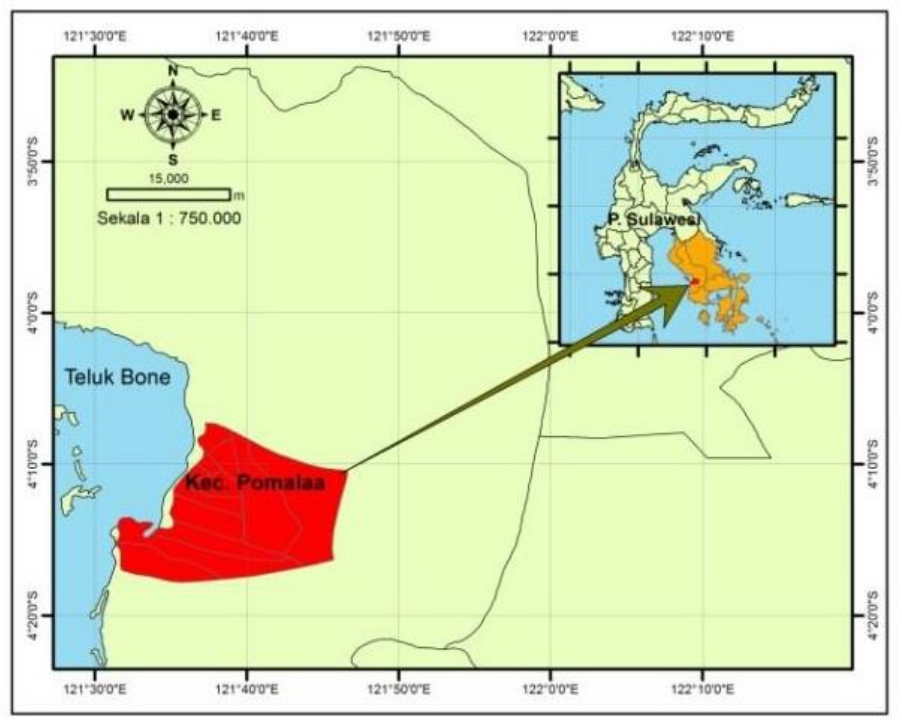

Gambar 3. Peta Daerah Pengambilan Data 
Data yang digunakan dalam penelitian ini merupakan data sekunder, diperoleh dari PT.Aneka Tambang Tbk Unit Geomin, Jakarta Selatan. Tempat pengambilan data lapangan (Akuisisi Data) dilakukan di daerah kuasa tambang PT. Aneka Tambang Tbk, Kecamatan Pomalaa, Kabupaten Kolaka, Sulawesi Tenggara.

\section{HASIL DAN PEMBAHASAN}

Hasil pengolahan data berupa Model Blok dan Titik datum dan inversi untuk Line 1 Bukit 1, Line 2 Bukit 1, Line 3 Bukit 1, Line 4 Bukit 1. Di bawah ini merupakan hasil dari pengolahan data.

Model Blok dan Titik Datum Apparent resistivity Line 1 Bukit 1

Line 1 Bukit1

ARRANGEMENT OF MODEL BLOCKS AND APPARENT RESISTIUITY DATUM POINTS

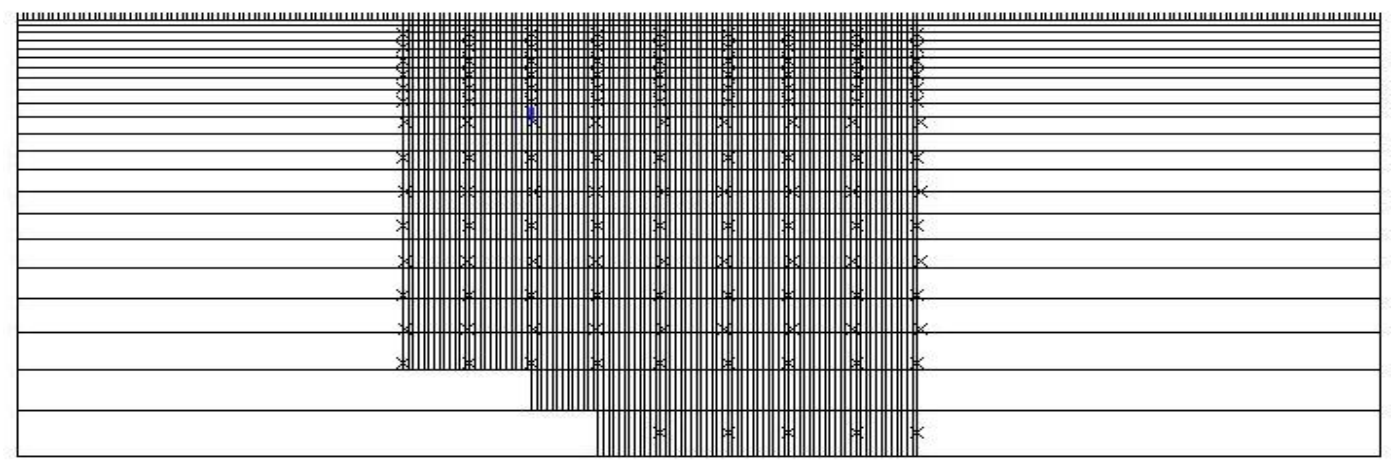

Model block

Datum point

Number of model layers is 22

Minimum pseudodepth is 2.05 .

Number of electrodes is 266 .

Hasil Inversi Line 1 Bukit 1

Number of model blocks 2181

Number of datum points 131

Unit electrode spacing $2.05 \mathrm{~m}$.

Unit electrode spacing
Maximum pseudodepth is 61.4 .

Gambar 4. Model Blok dan Titik Datum Apparent Resistivity.

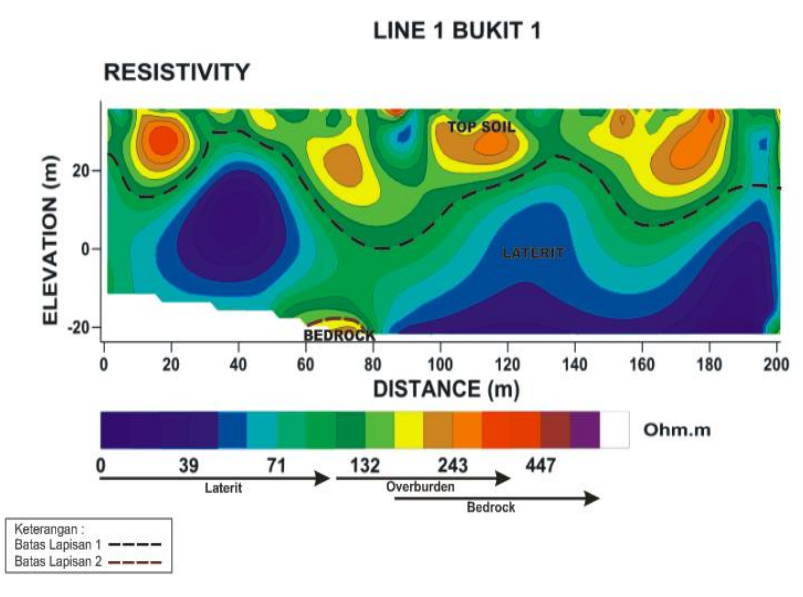

Gambar 5. Citra 2D Penampang Nikel Laterit Line 1 Bukit 1.

Line 2 Bukit 1

Model Blok dan Titik Datum Apparent resistivity Line2 Bukit 1 
Line 2 Bukit1

ARRANGEMENT OF MODEL BLOCKS AND APPARENT RESISTIUITY DATUM POINTS

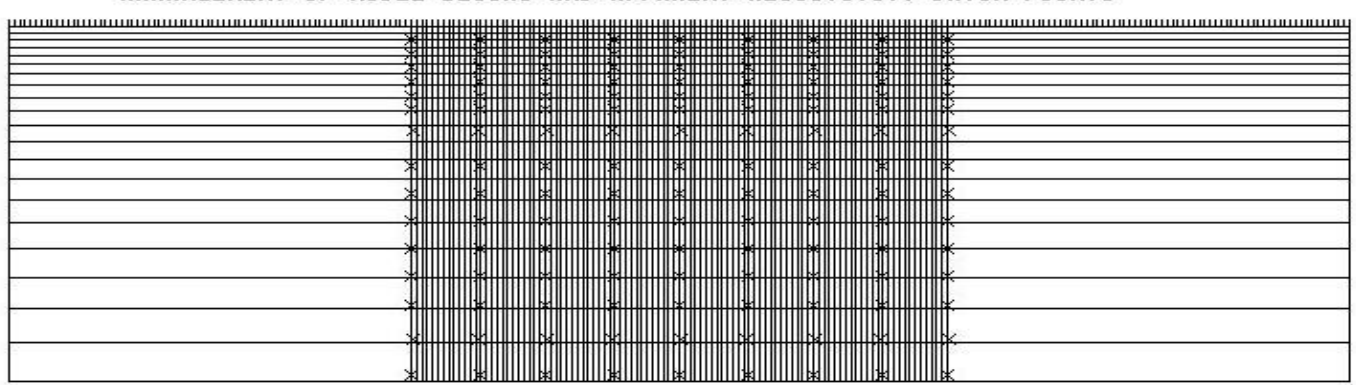

\section{Model block}

* Datum point

Number of model layers is 20

Minimum pseudodepth is 2.05.

Number of electrodes is 251.

Gambar 6. Model Blok dan Titik Datum Apparent Resistivity.

\begin{abstract}
Number of model blocks 2040
\end{abstract}
Number of datum points 135

Unit electrode spacing $2.00 \mathrm{~m}$.

Maximum pseudodepth is 51.2 .

Hasil Inversi Line 2 Bukit 1

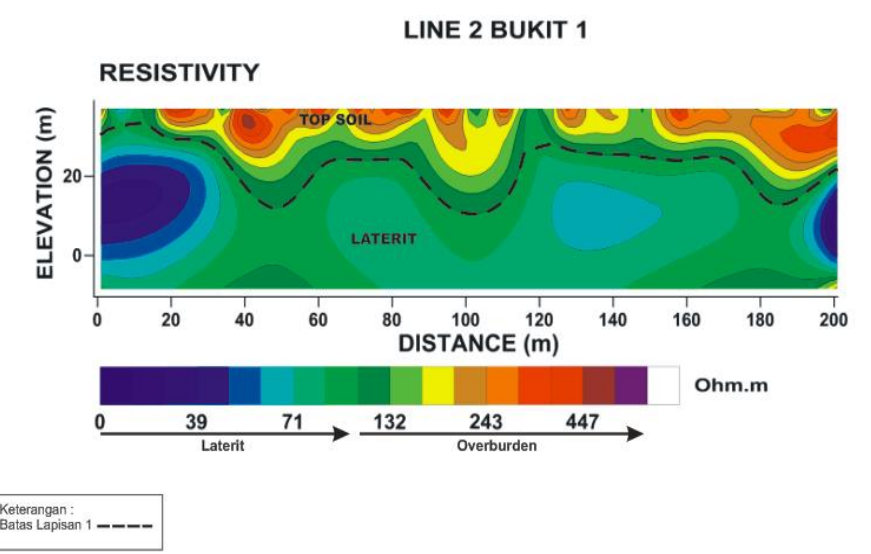

Gambar 7. Citra 2D Penampang Nikel Laterit Line 2 Bukit 1.

Line 3 Bukit 1

Model Blok dan Titik Datum Apparent resistivity Line 3 Bukit 1

Line 3Bukit1

ARRANGEMENT OF MODEL BLOCKS AND APPARENT RESISTIUITY DATUN POINTS

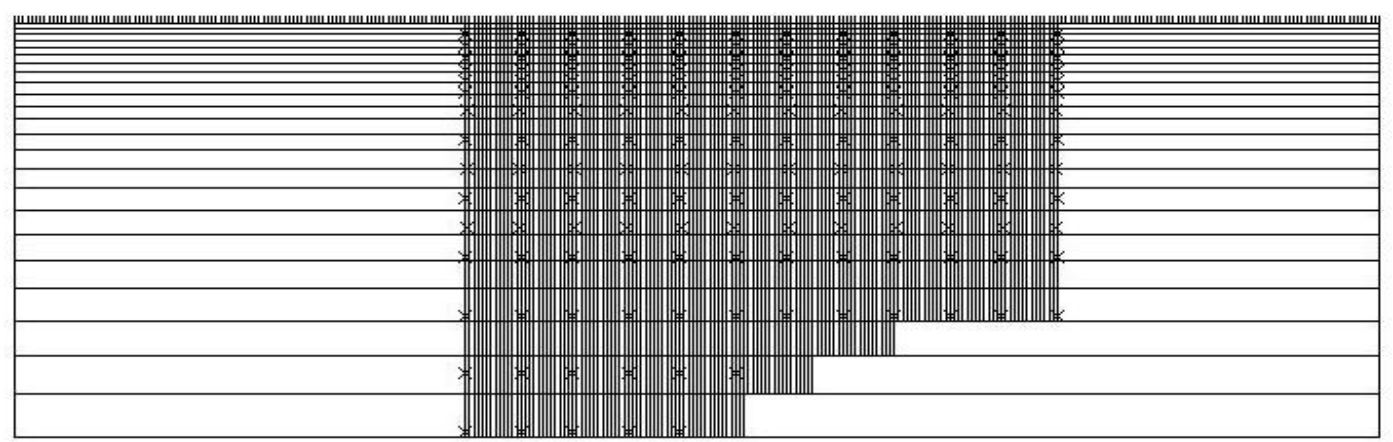

Model block

Datum point

Number of model layers is 23

Minimum pseudodepth is 2.65 .

Number of electrodes is $\mathbf{3 1 9}$.
Number of model blocks 3052

Number of datum points 167

Unit electrode spacing $2.00 \mathrm{~m}$.

Maximum pseudodepth is 71.7 .

Gambar 8. Model Blok dan Titik Datum Apparent Resistivity.

Hasil Inversi Line 3 Bukit 1 


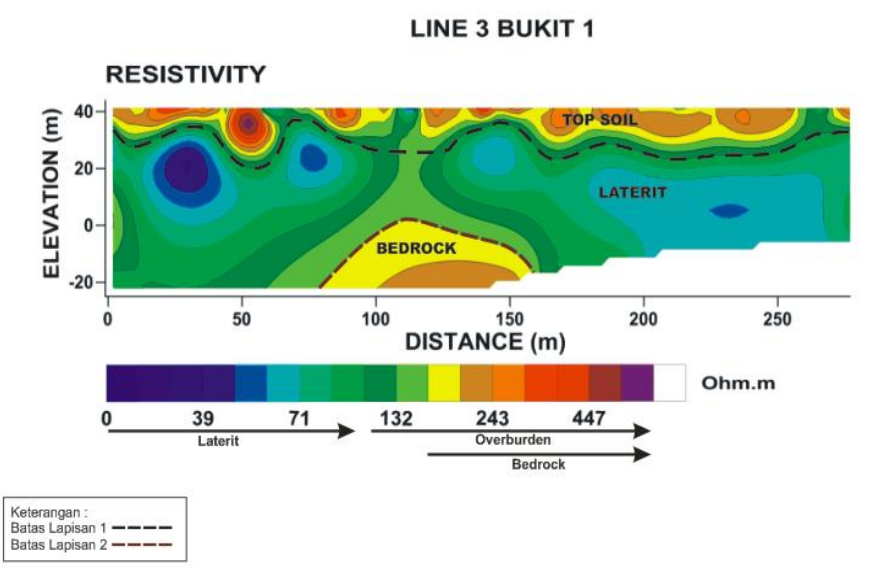

Gambar 9. Citra 2D Penampang Nikel Laterit Line 3 Bukit 1.

Line 4 Bukit 1

Model Blok dan Titik Datum Apparent resistivity Line 4 Bukit 1

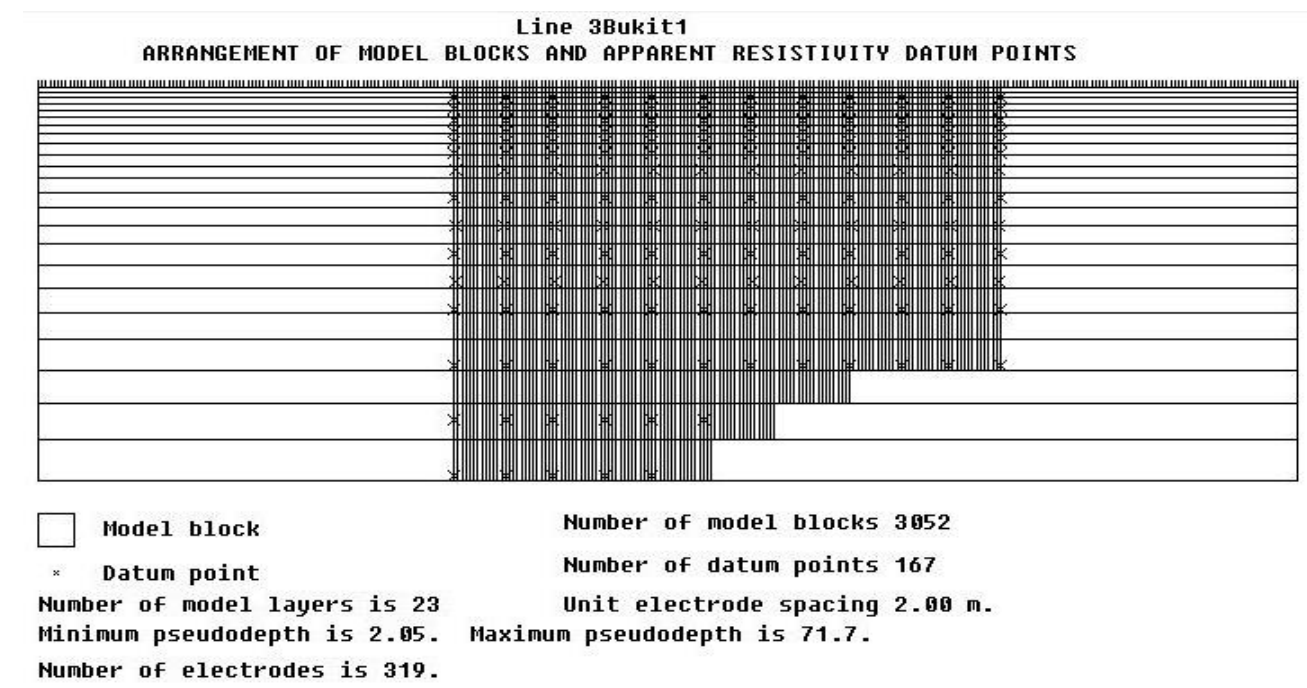

Gambar 10. Model Blok dan Titik Datum Apparent Resistivity.

Hasil Inversi Line 4 Bukit 1

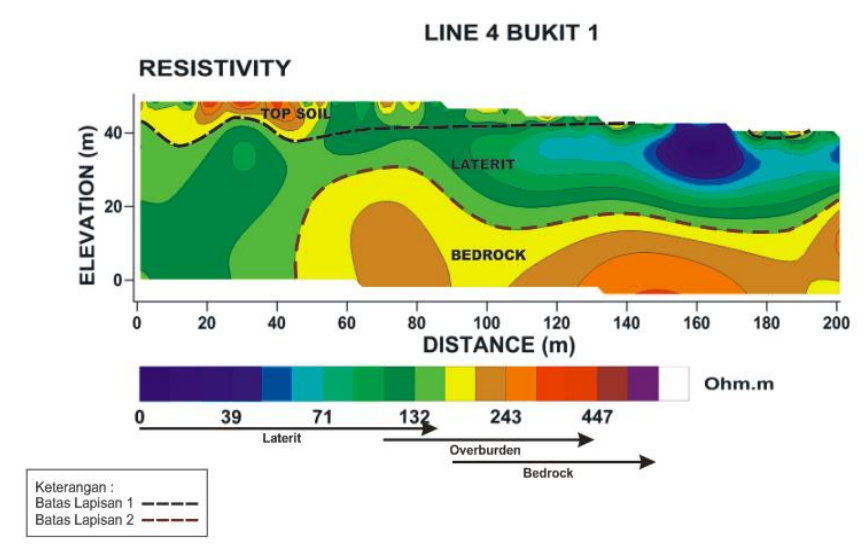

Gambar 11. Citra 2D Penampang Nikel Laterit Line 4 Bukit 1.

\section{ANALISIS DAN INTERPRETASI}

Daerah penelitian berupa bukit. Pada setiap (line 1, line 2, line 3 dan line 4) spasi minimal antara elektroda adalah $4 \mathrm{~m}$. Line 1 Bukit 1 terdiri dari 9 titik sounding yang ditandai dengan nama patok 0, 25, 50, 75, 100, 125, 150, 175, 200. Pada Patok 0-75, pengukuran 
dilakukan dengan spasi maksimal $100 \mathrm{~m}$ sedangkan pada patok 100 sampai 200 pengukuran dilakukan sampai spasi maksimal 120m. Terdapat 131 datum pada line ini. Line 2 Bukit 1 juga terdiri dari 9 titik sounding yang ditandai dengan nama patok (mid point) seperti pada line 1 yaitu $0,25,50,75,100,125,150,175,200$. Terdapat 135 datum pada line ini dengan spasi maksimal antara elektroda adalah 100m. Line 3 Bukit 1 terdiri 12 titik sounding yang ditandai dengan nama patok (mid point) $0,25,50,75,100,125$, $150,175,200,225,250,275$. Terdapat 167 Datum pada line ini dengan spasi maksimal antara elektroda adalah $140 \mathrm{~m}$. Line 4 Bukit 1 terdiri dari 9 titik sounding yang ditandai dengan nama patok seperti pada line 1 dan line 2 , yaitu $0,25,50,75,100,125,150,175$, 200. Terdapat 167 datum pada line ini dengan spasi maksimal antara elektroda adalah $100 \mathrm{~m}$.

Data hasil pengukuran dimodelkan penampang 2D menggunakan Res2Dinv dan disajikan menggunakan Surfer 12. Terdapat empat line (lintasan) penampang nikel laterit. Setiap line dibagi menjadi tiga lapisan yaitu Overburden (Top soil), Zona Laterit (Limonit dan Saprolit), dan Bedrock. Zona top soil dan bedrock secara umum memiliki resistivitas yang lebih tinggi dari zona laterit. Pada pemodelan ini, zona top soil berada pada resistivitas 120$350 \mathrm{ohm} . \mathrm{m}$, zona laterit 0-120 ohm.m, dan zona bedrock 150-500 ohm.m. Dengan perkiraan luas daerah sebesar $99.000 \mathrm{~m}^{2}$ dengan ketebalan zona laterit $30 \mathrm{~m}$ di bawah permukaan diperoleh volume zona nikel laterit sebesar $2.970 .000 \mathrm{~m}^{3}$.

Zona Top soil (Overburden) merupakan zona paling atas dari zona nikel laterit, mengandung campuran tanah dan biji besi laterit yang berwarna merah-cokelat tua, dengan ketebalan antara beberapa sentimeter sampai beberapa meter (rata-rata \pm 1-2 meter).

Zona laterit (Limonit dan Saprolit) memiliki resistivitas rendah karena merupakan zona alterasi batuan. Zona ini umumnya merupakan daerah saturasi yang lembab/basah. Seperti yang telah diketahui bahwa daerah lembab dan basah mengandung air, air merupakan penghantar listrik yang baik (konduktivitas tinggi) oleh karena itu resistivitasnya rendah. Daerah ini mengandung kadar nikel tinggi. Zona Bedrock merupakan merupakan batuan dasar, lapisan paling bawah yang terdiri dari batuaan peridotit/serpentin. Batuan- batuan ini merupakan batuan beku, sehingga memiliki resistivitas yang cukup tinggi.

Pada Gambar 5, line 1, terlihat bahwa zona laterit nikel memiliki resistivitas yang sangat rendah, berkisar $0-120 \mathrm{ohm} . \mathrm{m}$, Zona top soil (overburden) memiliki resistivitas di sekitar 120 ohm.m - 350 ohm.m , dan Zona Bedrock di sekitar 150 ohm.m. Batasan antara zona laterit dan bedrock berada di sekitar kedalaman $60 \mathrm{~m}$ dari permukaan.

Pada Gambar 7, line 2, terlihat bahwa zona laterit nikel memiliki resistivitas rendah, berkisar $0-120$ ohm.m, Zona top soil (overburden) memiliki resistivitas di sekitar 120 ohm.m - 350 ohm.m. Kedalaman yang diperoleh pada line 2 yaitu sekitar 50 m. Zona Bedrock tidak terlihat di kedalaman ini.

Pada Gambar 9, line 3, terlihat bahwa zona laterit nikel memiliki resistivitas yang sangat rendah, berkisar $0-120 \mathrm{ohm} . \mathrm{m}$, Zona top soil (overburden) memiliki resistivitas di sekitar 120 ohm.m - 350 ohm.m , dan Zona Bedrock di sekitar 150 ohm.m. Batasan antara zona laterit dan bedrock mulai ada di sekitar kedalaman $40 \mathrm{~m}$ dari permukaan.

Pada Gambar 11, line 4, terlihat bahwa zona laterit nikel memiliki resistivitas yang sangat rendah, berkisar $0-120 \mathrm{ohm} . \mathrm{m}$, Zona top soil (overburden) memiliki resistivitas di sekitar 120 ohm.m - 350 ohm.m , dan Zona Bedrock di sekitar 150 ohm.m. Batasan antara zona laterit dan bedrock berada di sekitar kedalaman $30 \mathrm{~m}$ dari permukaan.

Tabel 1. Nilai Resistivitas dan Kedalaman Setiap Lapisan (Zona).

\begin{tabular}{lll}
\hline Lapisan & Nilai Resistivitas (Ohm.m) & Kedalaman $(\mathrm{m})$ \\
\hline Overburden (Top soil) & $120-750$ & $0-30$ \\
Laterit & $0-120$ & $10-60$ \\
Bedrock & $>200$ & $>50$ \\
\hline
\end{tabular}




\section{KESIMPULAN}

Dari hasil yang diperoleh, dapat disimpulkan Zona top soil (overburden) memiliki resistivitas 120-750 ohm.m, zona laterit 0-120 ohm.m, dan zona bedrock memiliki resistivitas lebih dari $200 \mathrm{ohm} . \mathrm{m}$. Zona overburden berada di kedalaman 0-30m, laterit berada di kedalaman 10-60m, zona bedrock berada dikedalaman lebih dari 50m. Dengan perkiraan luas daerah sebesar $99.000 \mathrm{~m}^{2}$ dengan ketebalan zona laterit $30 \mathrm{~m}$ di bawah permukaan diperoleh volume zona nikel laterit sebesar $2.970 .000 \mathrm{~m}^{3}$.

\section{DAFTAR PUSTAKA}

[1] AizebeokhaiA.P., Olayinka, A.I. dan Singh, V.S., 2010, Aplication of 2D and 3D Geoelectrical Resistivity Imaging For Engineering Site Investigation In a Crystalline Basement Terrain, Southwestern Nigeria. Journal of Enviromental Earth Sciences, 1481-1492.

[2] Hamdan,H., et al., 2012, 2D and 3D imaging of the metamorphic carbonates at Omalos plateu/polje,Crete, Greece by employing independent and joint inversion on resistivity and seismic data. International Journal of Speleology, 41(2),199-209.

[3] Virman, Endang H., Risal P., Muhammad A.M., 2014, Penentuan Profil Nikel Laterit Menggunakan Metode Geolistrik Tahanan Jenis Daerah Entrop Kota Jayapura. Prosiding Seminar Nasional Sains dan Pendidikan Sains IX, Fakultas Sains dan Matematika, UKSW Salatiga, Vol.5, No.1.

[4] Hendrajaya, L. dan Arif, I., 1990, Metode Geolistrik Tahanan Jenis. ITB : Bandung.

[5] Telford, W.M., 1990, Applied Geophysicst. Cambridge University Press.

[6] Loke, M.H. 2001. Tutorial : 2-D and 3-D Electrical Imaging Surveys. Malaysia. Penang.

[7] Aizebeokhai,A.P., 2010, 2D and 3D Geoelectrical Resistivity Imaging: Theory and Field Design. Scientific Research and Essay, 5(23), 3592-3605.

[8] Waheed. A., 2004, Nickel Laterites-A Short Course : Chemistry, Mineralogy, and formation of nickel laterites (unpublished).

[9] Sutisna, Deddy T., et al, 2006, Perancangan Eksplorasi Cebakan Nikel Laterit Di Daerah Wayamli, Teluk Buli, Halmahera Timur. Makalah Ilmiah. Buletin Sumber Daya Geologi Vol. 1 No.3

[10] Elias, M.,2001, Nickel Laterite Deposits - Geological Overview, Resorces and Exploitation. Australia : CSA Australia

[11] Nukdin, Ernita, 2012, Geologi dan Studi Pengaruh Batuan Dasar Terhadap Deposit Nikel Laterit Daerah Taringgo Kecamatan Pomalaa Kabupaten Kolaka Propinsi Sulawesi Tenggara. Jurnal Ilmiah MTG, Vol.5, No.2. 